\title{
When bronchial obstruction is not only asthma: a case of congenital cystic adenomatoid malformation type 0
}

\author{
Luciana Indinnimeo ${ }^{1}$, Valeria Lollobrigida², Taulant Melengu², Maria Palma Carbone², Azzurra Cesoni Marcelli², \\ Francesca Occasi ${ }^{2}$, Valentina De Vittori ${ }^{2 *}$, Marzia Duse ${ }^{2}$
}

From EAACI International Severe Asthma Forum (ISAF 2012)

Gothenburg, Sweden. 11-13 October 2012

Congenital cystic adenomatoid malformation (CCAM) is one of the most common congenital lung anomalies. It is a rare pulmonary alteration, characterized by lung tissue dysplastic or hamartomatous, mixed with normal tissue. The injury is likely related to an insult during embryological development with altered terminal bronchiolar structures. We describe an unusual case of a boy came to our observation at the age of 12 years, for mild persistent bronchial asthma with exercise induced asthma, allergic to dust mites, pollens of grasses, Cypress and to epithelium of the cat. At birth, respiratory distress treated with oxygen therapy, which resolved on the second day of life. For the first two years of life, he had recurrent episodes of wheezing requiring bronchodilator therapy and oral corticosteroids; subsequently, he presented rare episodes of bronchospasm, and asthma induced from intensive exercise. He practiced martial arts at a competitive level. The routine spirometry showed FEV1 58.5\% and MEF50 $24.7 \%$, values that were not reversible after salbutamol, despite therapy with CSI + LABA. The chest X-ray showed thickening of the right parietal pleura and of the apical one and evidence of fibrotic striae. The chest HRCT revealed mosaic bilateral parenchymal destruction, bronchiectasis and multiple formations nodules like, poly-lobed with blurred margins, the larger of a diameter of $12 \mathrm{~mm}$. The bronchioloalveolar lavage was normal. Inflammatory, autoimmune, infectious and other congenital diseases were excluded. The histology of the lung biopsy obtained by thoracotomy surgery, suggested the diagnosis of CCAM type 0 without malignancy.

2Università La Sapienza, Policlinico Umberto 1, Servizio di Allergologia ed Immunologia Pediatrica, Italy

Full list of author information is available at the end of the article

\section{Author details}

${ }^{1}$ Università La Sapienza, Policlinico Umberto 1, Italy. ${ }^{2}$ Università La Sapienza Policlinico Umberto 1, Servizio di Allergologia ed Immunologia Pediatrica, Italy.

Published: 3 May 2013

doi:10.1186/2045-7022-3-S1-P24

Cite this article as: Indinnimeo et al: When bronchial obstruction is not only asthma: a case of congenital cystic adenomatoid malformation type 0. Clinical and Translational Allergy 2013 3(Suppl 1):P24.

Submit your next manuscript to BioMed Central and take full advantage of:

- Convenient online submission

- Thorough peer review

- No space constraints or color figure charges

- Immediate publication on acceptance

- Inclusion in PubMed, CAS, Scopus and Google Scholar

- Research which is freely available for redistribution

Submit your manuscript at www.biomedcentral.com/submit
() Biomed Central

\section{Biomed Central}

